\title{
Jonathan S. McIntosh, The flame imperishable: Tolkien, St. Thomas, and the metaphysics of Faërie
}

\author{
Euan Grant
}

\begin{tabular}{|l|l|}
\hline Date of deposit & $17 / 09 / 2019$ \\
\hline Document version & Author's accepted manuscript \\
\hline Access rights & $\begin{array}{l}\text { Copyright @ 2019. Edinburgh University Press. This work has } \\
\text { been made available online in accordance with publisher policies } \\
\text { or with permission. Permission for further reuse of this content } \\
\text { should be sought from the publisher or the rights holder. This is } \\
\text { the author created accepted manuscript following peer review and } \\
\text { may differ slightly from the final published version. }\end{array}$ \\
\hline $\begin{array}{l}\text { Citation for } \\
\text { published version }\end{array}$ & $\begin{array}{l}\text { Grant, E. (2018). Jonathan S. McIntosh, The flame imperishable: } \\
\text { Tolkien, St. Thomas, and the metaphysics of Faërie. Journal of } \\
\text { Inklings Studies, 8(2), 200-202 }\end{array}$ \\
\hline $\begin{array}{l}\text { Link to published } \\
\text { version }\end{array}$ & \begin{tabular}{l} 
https://doi.org/10.3366/ink.2018.0018 \\
\hline
\end{tabular}
\end{tabular}

Full metadata for this item is available in St Andrews Research

Repository at: https://research-repository.st-andrews.ac.uk/

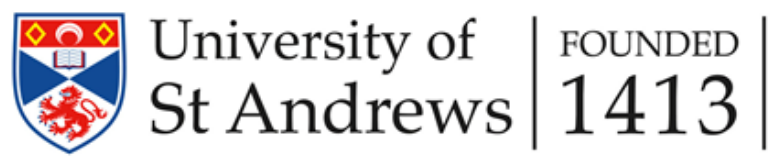


The Flame Imperishable offers two accounts of Tolkien as a Thomist metaphysical thinker: one broader and one narrower. On the one hand, Aquinas appears as doctor communis over against pagan Neoplatonists or Manichaeans, and serves as a partner for Tolkien principally because, from the promulgation of Aeterni Patris by Leo XIII, 'Thomism' was Catholic doctrine, not to mention Catholic philosophy. St Thomas also appears in this book, however, over against William of Ockham and Peter Lombard, and he appears in person, with McIntosh working from Thomas' own texts, in preference to the scholastic or neo-scholastic handbooks and treatises of Tolkien's own day. It is not Catholic metaphysics in general which is at issue here, but the pertinence of the specific figure and writings of Aquinas himself.

In other words, McIntosh makes two major claims in this book. The first is that there are conscious metaphysical commitments within Tolkien's work, especially as worked out in the Ainulindalë and the lesser-known Athrabeth, which are robustly Christian and Catholic in character. The second is that the best means of elucidating this is by comparison of Tolkien's work to the primary texts of St Thomas. In the first he is eminently successful; in the second both his success, and his rationale in seeking it in the first place, is less clear.

A summary of some key disputes will suffice to give a flavour of the arguments on the first head. Since the metaphysical care taken in the construction of Tolkien's secondary world is quite clear, the major interlocutors are those who have proposed readings which downplay Catholic themes in favour of alternative philosophical backgrounds: Verlyn Flieger and in the account of creation, who proposes something more like Neoplatonist emanation than divine creation; Tom Shippey for Tolkien's account of evil as proposing a 'running ambiguity' between Augustinian and Manichaean strands. Chapters cover debates over the metaphysics of divine presence and action in creation, God's role in subcreation and creaturely freedom, creation as the gift of being, the status of elves and angels, and the Augustinian account of evil. McIntosh's treatment of these ideas, particularly when addressing the arguments of other interpreters is competent and credible, and his use of Thomas' thinking - even were it not to involve a claim of direct influence on Tolkien - would be sufficient to demonstrate that these critiques, if they are reported fairly, rest on failures to understand the positions which they oppose. St Thomas functions as someone who's thought had already integrated all that a Christian might wish to find in neoplatonic accounts of hierarchies of being or 'positive' accounts of evil, and so one who outmanoeuvres attempts to read these elements in Tolkien against the prevailing Catholic doctrinal current. This is particularly true in the fifth and final chapter on evil - in my judgement the most exciting in the book - which demonstrates, by means of the difficult figure of Ungoliant, the way in which a privative view of evil can nonetheless provide a metaphysical background for the very real power of evil as perversion of the good.

In these discussions, Thomas appears more as a paragon of the Catholic tradition over against its challengers, than as an individual and sometimes (particularly on angels) idiosyncratic thinker. His invocation is less obviously apt where it is not called upon for philosophical or theological clarification in an ongoing academic conversation. Two examples stand out here. First, the possibility of sub-creation as a counter-factual act of a fantastical imagination draws out some discussion of the metaphysics of creation in Thomas and Ockham, in which Ockham - not wholly surprisingly - is ultimately rejected. It might be fair to ask, however, whether Ockham's understanding of possibility is really the best foil for St Thomas' intellectualist, Aristotelian realism about creation. In imagining new species - or more significantly, different ways in which existing species might have been created by God, as in the case of the Valar as demigurgic angels - might it not have made more sense to reach for Scotus rather than Ockham, and to explore the possibilities of a doctrine of creation which is voluntarist without being nominalist? To go further: given the cross-fertilisation of Thomist, Scotist, and nominalist strands through the long history of post-mediaeval scholasticism and Catholic education prior to the disturbances of the mid-twentieth century, might it not have been more productive to investigate how these themes were understood in Tolkien's more immediate milieu? As 
a nominalist, Ockham never really convinces as a contender in a book of this sort, but that does not quite imply that Thomas is the only, or even the most natural, mediaeval or later alternative.

If the attribution of Tolkien's thought to Thomas neglects specific interesting alternatives in some instances, it seems also to neglect the very broadness of 'Thomist' structures of thought in others. Since Tolkien's Valar represent such a clear departure from Thomas' understanding of angels, the suggestion that the underlying motive in their depiction is Thomist simply as proposing a hierarchical cosmology seems rather over-specific. The Great Chain of Being is hardly the invention of one thinker, of one era, or even of one continent, and to see the hierarchical motive as significantly 'Thomist', rather than attempting to trace its wider antecedents and Tolkien's literary sources - or allowing this already to have been done - seems somewhat excessive.

That I reach for these criticisms at all, of course, shows that on a broader level this book is a success. It is because the case for Tolkien as a Catholic metaphysical thinker is sound and well-made that questions of the specific form and historical derivation of his Catholic metaphysics are thereby the more pointed. As a reader of Thomas and later scholastics they interest me particularly, but perhaps a deeper investigation into the precise historical roots of Tolkien's Catholic philosophy would have taken this book to unwieldy lengths. For readers of Tolkien, however, The Flame Imperishable amply demonstrates the strengths, significance, and beauty of the metaphysical themes, rung loudest by Thomas and echoed through the whole Catholic scholastic tradition, which reverberate through the sub-creation of Middle Earth, and sound in the music of the Ainur. 